\title{
Renewables in pasturable livestock production
}

\author{
Olga Gerasimova ${ }^{1}$, Mikhail Novikov ${ }^{2}$, Victor Smelik ${ }^{2}$, Olga Bykova ${ }^{3, *}$, and Olga Loretts ${ }^{3}$ \\ ${ }^{1}$ Federal State Budgetary Educational Institution of Higher Education "State Agricultural Academy of \\ Velikie Luki", Velikie Luki, Russia. \\ ${ }^{2}$ Federal State Budgetary Educational Institution of Higher Education «Saint-Petersburg State Agrarian \\ University» (FSBEI HE SPb SAU), Saint Petersburg, Russia. \\ ${ }^{3}$ Federal State Budgetary Educational Institution of Higher Education «Ural State Agrarian University» \\ (FSBEI HE USAU), Ekaterinburg, Russia
}

\begin{abstract}
The purpose of researches formation of perspective technology of maintenance of KRS in the conditions of a pasture in the absence of stationary power supply. The method - the main orientation is transfer of all technology for power security to nonconventional and renewable sources. It is planned to use at the same time energy of the sun, wind, a bioenergy and energy of the small rivers, that is sources which pastures are generally characteristic. Results the complex of nonconventional means of power supply of technological processes in pasturable livestock production which unconditional positive property is its renewability and environmental friendliness is defined in particular our country has the most high wind power potential in the world. The conclusion the scheme of the master plan of a pasturable complex, is developed for farms of the Pskov region with objects of the power sources planned to use in its perspective option.
\end{abstract}

\section{Introduction}

Real support for small producers can be got due to use nonconventional and renewables (NVIE). In the European countries, this direction began to develop generally in 70 the 80th years of last century. In our country, having large supplies of fossil energy carriers - oil, gas, geothermal sources and other, began to pay to development of nonconventional sources attention in connection with reduction of stocks of natural energy carriers only in recent years [1].

Creation in Russia of the legislative base of use of NVIE became a positive factor. Therefore, the law "About Power Industry" (2007) laid the legal foundation of application of the electric generator installations on NVIE. The law adopted by the State Duma and the Federation Council "About state policy in the sphere of use of nonconventional renewables" is the legal act on establishment of minimum admissible economic and organizational bases of development of the industry in modern conditions.

Later, in 2013 and 2015 some more the key orders and resolutions of the Government of the Russian Federation contributing to the development [2] of alternative power engineering and the defined main directions of state policy in the sphere of increase in energy efficiency were accepted:

\footnotetext{
*Corresponding author: olbyk75@mail.ru
} 
small hydroelectric power stations with a rated capacity less than $25 \mathrm{MW}$;

the generating installations on the basis of solar energy;

the generating installations on the basis of wind power;

the generating installations on the basis of geothermal energy of natural underground heat carriers;

the generating installations on the basis of low-potential thermal energy of the earth, air, water, including sewage;

the generating installations on the basis of biomass and biogas.

\section{Materials and Methods}

Use of energy of the sun.

For conditions of pastures, the most optimum direct use, namely thermal and photo thermoelectric transformation of solar radiation [3].

Radiant energy of the sun (solar radiation) is the main source of energy due to which various processes both in the atmosphere and on the Earth's surface are make. Passing through the atmosphere, solar radiation is partially absorber by various gases, dissipates the atmosphere, various impurity and clouds. To the Earth's surface, it arrives in the form of direct radiation and disseminated, making in total radiation.

The quantity of radiation arriving to the Earth's surface is define, first, by astronomical factors: day length and height of the sun over the horizon.

The day length, and, therefore, and the possible duration of sunshine, considerably changes within a year [4]. The longest day in Pskov (18 h are 20 min. old) falls on June 22 (day of a summer solstice), and the shortest (6 h are $08 \mathrm{~min}$. old) - for December 22 (day of a winter solstice). These days height of the sun at noon equals 55 and $8.2^{\circ}$, respectively.

The possible duration of sunshine in Pskov in a year is $4506 \mathrm{~h}$, and actual - only $1738 \mathrm{~h}$ and its values under the influence of overcast strongly fluctuate from year to year. Also such days, usually their 115 in a year when throughout the day sunshine completely is absent because of existence of continuous overcast are frequent.

Solar collectors

The solar collector is effective for year-round application in all territory of Russia. The number of sunny days during the period and in a zone of pasturable contents is about 2000 hours that considerably exceeds the period of maintenance of KRS (150 . 155 days) [4]. Efficiency of a solar collector makes not less than $95 \%$. Has thermal isolation of the heat exchanger of $75 \mathrm{~mm}$. Has high efficiency and productivity in the conditions of low solar insolation. It is mounted on a frame from aluminum or stainless steel for installation on any type of a roof: from vertical surfaces to horizontal.

The simplest device with the natural displacement of the coolant is sow in Fig. 1.

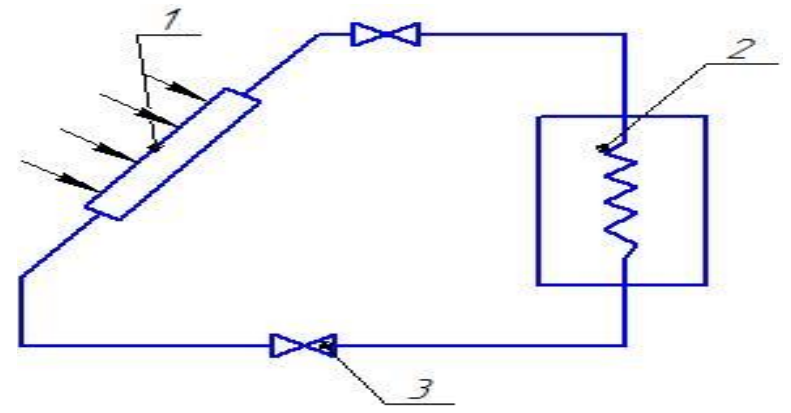

Fig. 1 The scheme of solar installation with the collector of the increased efficiency: 1 - solar collector, 2 - a storage container (heat exchanger), 3 - a valve. 


\section{Solar Power Plants (SPP)}

Solar power plants [5] - the engineering construction serving for conversion of solar radiation. The main indicator - the solar batteries consisting of thin layers from semiconductor materials capable to transform solar energy to direct electric current [5].

Photo-electric transformers differ in reliability, stability, and service life is almost not limited. They can transform both the direct, and scattered sunlight. Process is environmentally friendly.

A small lot, simplicity of service, modular type of construction allows to create installations of any power.

Shortcomings: high cost, low efficiency, continuous change of an incidence angle of beams. One of ways of conversion of solar energy in electric is the construction of heliothermal power stations (fig. 2)[5].

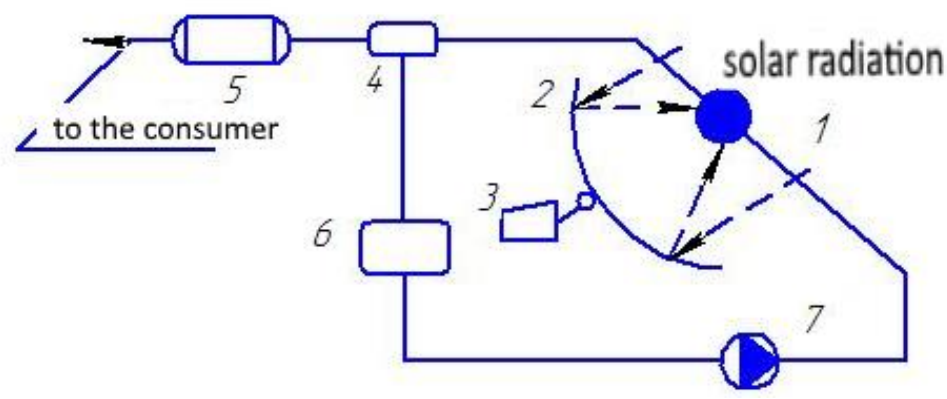

Fig. 2 Heliothermal (thermodynamic) solar power station:

1 - solar copper; 2 - the collector concentrating; 3 - navigation system; 4 - steam turbine; 5 - electric generator; 6 - condenser; 7 - pump.

Use of wind power

Now the wind power share in the total production of the electric power is insignificant [3]. However, in the next years the situation will change to the best. Our country has the biggest in the world wind power potential - about 40 billion $\mathrm{kWh}$ of the electric power a year. Thus, wide use of wind power installations (VEU) and, in particular, small wind turbines for pasturable livestock production, is perspective.

Atmospheric circulation causes prevalence in Pskov for a year of the winds Yuzhnogo and Southwest the directions.

Their joint repeatability, which is in the fall and in the winter $35 \ldots 40 \%$ in a month by summer, decreases up to $25 \%$. In the spring and at the beginning of summer of a bike repeatability of Northwest winds (18 .. 20\%). In the summer in Pskov often there are winds of a northern quarter (Northern, Northwest, Northeast). Their total repeatability at this time dostigayet $35 \ldots 40 \%$ in a month, and in cold summer $55 \ldots 60 \%$.

From all speeds noted in Pskov, more often others (in $50 \ldots 60 \%$ of cases) speeds $2 \ldots 5$ $\mathrm{m} / \mathrm{s}$ meet. With increase in speeds of wind their repeatability, as a rule, sharply decreases, and at a speed of $8 \mathrm{~m} / \mathrm{s}$ and more it is necessary only from $2.7 \%$ in August and up to $9.3 \%$ in December. Strong wind $(15 \mathrm{~m} / \mathrm{s}$ and more) happens in Pskov infrequently, on average 11 days in a year. The greatest number of days with such wind in a month does not exceed $3 \ldots 5$.

Strengthening of wind to $15 \ldots 17 \mathrm{~m} / \mathrm{s}$ and $17 \ldots 20 \mathrm{~m} / \mathrm{s}$ is connecter in the summer with passing through a zone of Pskov of deep cyclones in the winter. Separate short-term rushes at the same time can reach even $25 \ldots 29 \mathrm{~m} / \mathrm{s}$. Once in 10 years in Pskov is possible wind of $21 \mathrm{~m} / \mathrm{s}$ and more, and once in 20 years $-23 \mathrm{~m} / \mathrm{s}$ and more.

Duration of big speeds of wind in Pskov is small. Therefore, wind, with a speed of $8 \mathrm{~m} / \mathrm{s}$ and more can last $50 \ldots 75 \mathrm{~h}$ in a month during the cold period and about $30 \mathrm{~h}-$ in the 
summer. In addition, more it is the share of the speed of $12 \mathrm{~m} / \mathrm{s}$ of $3 \mathrm{~h}$ in May up to $17 \mathrm{~h}$ in February at its continuous preservation on average $2 \ldots 7 \mathrm{~h} \mathrm{[4]}$.

Having carried out the analysis, it is possible to note with confidence that climatic conditions of the Pskov region quite correspond for use of such nonconventional sources as energy of the sun and wind. Such installations will allow to receive hot water, the electric power, mechanical energy in various places where there is a need for these types of energy. Essential plus of such installations is their autonomy, ease in service, ecological purity.

In addition, use of installations on nonconventional renewables has to be economically justified.

Influence on ecology

Ecologists make a lot of claim to wind power. It is result acting on people noise, infrasonic fluctuations and vibrations, near wind farms animals and birds cease to lodge. During the work of a set of wind generators on big squares perhaps local decrease in force and change of a configuration of winds. The additional problem is created in need of utilization of the blades, which exhausted the value [7]. Nevertheless, the total ecological damage from wind power is significantly lower in comparison with traditional ways of generation of energy. The exception is mаке by a problem of utilization of blades of the wind unit made of composite materials. However, in relation to conditions of pasturable livestock production the above problems are not prevailing.

Use of bio power stations

The problem of use of a bioenergy acquires the increasing relevance as abroad in recent years, and in the CIS countries as a way of processing of biomass an anaerobic fermentation.

At the same time, that especially significantly joint development of electric and thermal energy is extremely necessary for small livestock farms of the pasturable direction -. And if to mean the livestock industries as directly connected with food and fodder crop production, then more perfect forms of recycling of activity of animals as primary source of production of eco-friendly organic fertilizers are relevant.

The essence of anaerobic process of processing is that for lack of oxygen some microorganisms are capable to receive energy, directly processing carbonaceous connections, producing at the same time methane $(\mathrm{CH} 4)$, carbon dioxide $(\mathrm{CO} 2)$ and associated gases (hydrogen, oxygen, ammonia, hydrogen sulfide, etc.). The received mix is biogas. At an anaerobic fermentation, for example, of manure, the following important problems especially relevant for conditions of pastures are solved:

- the energy carrier which in itself even without cleaning of foreign inclusions has rather high energy content - from 20 to $25 \mathrm{MDzh} / \mathrm{m} 3$ is made;

- the useful ecological effect is gained (a methane anaerobic fermentation of manure the udobritelnykh of substances in digestible with plants a mineral form provides its deodorization, expulsion of helminthes, destruction of ability of seeds of weed plants to viability, the translation);

- highly effective organic fertilizer at which substances, nutritious for a plant, - nitrogen, phosphorus, potassium - are practically not lost turns out.

Bio installations along with hydroelectric power stations, solar and wind power stations increase the presence in the area of production of electric energy. Use of heat of combustion of biomass became the innovative decision in search of fuel alternatives.

Proceeding from the previously mentions, it is possible to draw a conclusion that obvious need for pasturable livestock production is development of systems of coproduction of different types of energy. These systems will allow to lower significantly costs of the consumed energy and to solve an important problem of peak loadings and shortcomings of the centralized systems [8].

In general, the cogeneration installations have considerable resource potential, and so advantages in reliability, range of power resources. 
Use of small hydropower

Technical potential of small hydropower in the world is more than 360 billion $\mathrm{kWh}$ a year, and its use in Russia does not exceed $1 \%$. As for a state on the Pskov region, this figure approaches the 100-th percent shares. In too time a construction on small waterways of small (MGES) and micro hydroelectric power station one of the economic directions of development of renewable energy. Potential of small hydropower consists of unused opportunities of the small and average rivers. The term "Micro Hydroelectric Power Station" is usually used for hydrounits with power from 3 to $100 \mathrm{~kW}$ (fig. 3), "Mini-hydroelectric power station" - up to $5000 \mathrm{~kW}$.

The small rivers up to $100 \mathrm{~km}$ long make about $99 \%$ of all rivers of the country in Russia, and their drain makes more than $30 \%$ of a total drain of all rivers.

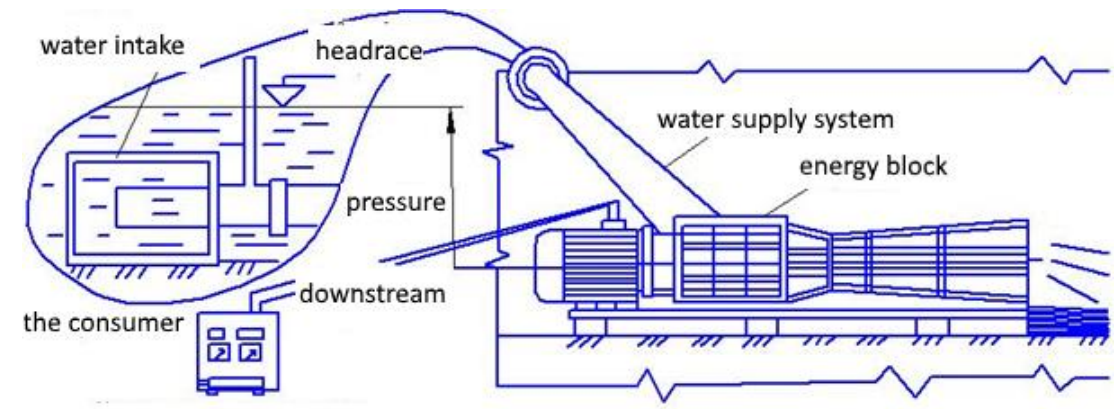

automatic control device

Fig. 3 Scheme of installation of micro hydroelectric power station

Comparative calculations showed that the cost of $1 \mathrm{kWh}$ of the electric power developed by micro hydroelectric power station is 5.5 times less, than the diesel station of the same power.

Small hydroelectric power stations do not conflict to the environment, and supplement and improve it. At a construction and operation micro and small - the hydroelectric power station as much as possible remains the surrounding nature, the fishery importance of reservoirs increases, there are no harmful effects of construction on properties and water qualities. In particular, the small hydroelectric power stations on the flat area working at low pressures does not demand flooding of inundated and valley lands. Cascades of low pressure dams and a chain of small reservoirs are arranged in ravines and beams, stabilization of the hydrological region small, to increase in their water content, accumulation and rational within a year, a flood drain promote.

\section{Results and Discussion}

Developed and approved power - the resource-saving technology (fig. 4) of production of high-quality milk provides performance of the following works: keeping of cows on the platform and bringing on milking; milking of cows; watering animals; termization, primary cooling and storage of milk; feeding by concentrates during milking; receiving warm water; removal of manure.

The technological line of milking and preprocessing of milk works as follows: the milked dry milk on the developed dairy line (patent No. 2549537) via the filter (patent No. 153451) goes to the installation for milk termization (patent 2536968, No. 166277) allowing to reduce quantity of harmful microorganisms to 190 thousand/ml. From where it arrives on primary cooling (patent No. 2486749; No. 2446679) where it is cooled up to the temperature of 14.0 
$\ldots 14.1^{\circ}$, temperature maintenance of storage of milk $6^{\circ} \mathrm{C}$ provides the final temperature of storage of milk 4 the reservoir cooler.

As source of vacuum it is used control systems of the water ring vacuum pump VVN-6 with the developed drive gear (patent No. 2624309). It provides high stability of vacuum and safety in operation and also cost reduction of energy depending on air consumption. It provides high stability of vacuum and safety in operation and also cost reduction of energy depending on air consumption.

Introduction of the complex of cars developed by us was carried out to APO collective Farm Rodina and JSC Krasnoye znamya, LLC APO Collective Farm Mayevsky of Pskov region.

Nonconventional power sources for conditions of pasturable livestock production are defined and proved. Sources are expected power supply of all complex of technology equipment at its maximum load. Besides, loading of the household sector of service staff is planned to accounting.

When using means of nonconventional power in the conditions of pastures there is a need of accumulation (accumulation) of energy. For the choice of the accumulator of energy (or completing from components) need to be known what character there has to be a device taking into account conditions of its use. Accumulators of energy are usually characterized:

- a type of the accumulated energy;

- amount of the accumulated energy;

- the consumed and given power;

- duration of charging and return of energy;

- Accumulation efficiency;

- specific heat-sink ability of the accumulator;

- the specific cost of the energy received from the accumulator.

It is possible to eliminate interruptions and fluctuations in power supply of consumers on a pasture when using no break power supply system, consisting of the electric power drive in the form of electrochemical accumulators (AB).

The scheme of the master plan of the pasturable complex developed for farms of the Pskov region and approved in two farms of the Pskov region is provided. Objects nonconventional and the renewables planned to use in perspective option of complex [9] are given in the upgraded version of the scheme.

Loading in the system of pasturable livestock, production (master plan) consists of loading of processing equipment (at the rate of 200 heads of KRS) and loadings of the household sector of service staff (fig. 4).

Loading of processing equipment:

The milking machine (with the vakkum-pump) - $4.5 \mathrm{~kW}$; The milk cooler $-4 \mathrm{~kW}$; Lamps of the general power $-0.15 \mathrm{~kW}$;

Electric motors:

Electric motor No. 1 of system of circulation of solar collector- 0.5 of $\mathrm{kW}$; Electric motor of vacuum pump No. 2 of the milking machine- 4 of kW; Electric motor No. 3 of giving of the heat carrier of the cogeneration block - $1 \mathrm{~kW}$; At the same time included loading power $\sim 10.15 \mathrm{~kW}$.

Loading of the household sector of service staff:

The refrigerator household - $300 \mathrm{~W}$; Two TVs - $140 \mathrm{~W}$; The washing machine $-1.5 \mathrm{~kW}$;

Lamps with a general power of $100 \mathrm{~W}$; At the same time included power up to $2.04 \mathrm{~kW}$. Inventor with rated power up to $3 \mathrm{~kW}$. Power arrester.

The total included power of $12.19 \mathrm{~kW}$. Autonomous power sources:

Electric motor of wind power installation of $3 \mathrm{~kW}$; Generator of the cogeneration block of $5.5 \mathrm{~kW}$; Generator of microhydroelectric power station $\sim 3 \mathrm{~kW}$; Photo-electric converter $\sim 2 \mathrm{~kW}$. 
Maximum total development of electric energy $\sim 13.5 \mathrm{~kW}$.

Autonomous sources of thermal energy:

Cogeneration block $\sim 50 \mathrm{kWh}$; Vacuum solar collector $\sim 1500 \mathrm{~W}$;

At the same time included power up to $5.5 \mathrm{~kW}$. Inventor with rated power up to $3 \mathrm{~kW}$. Power arrester.
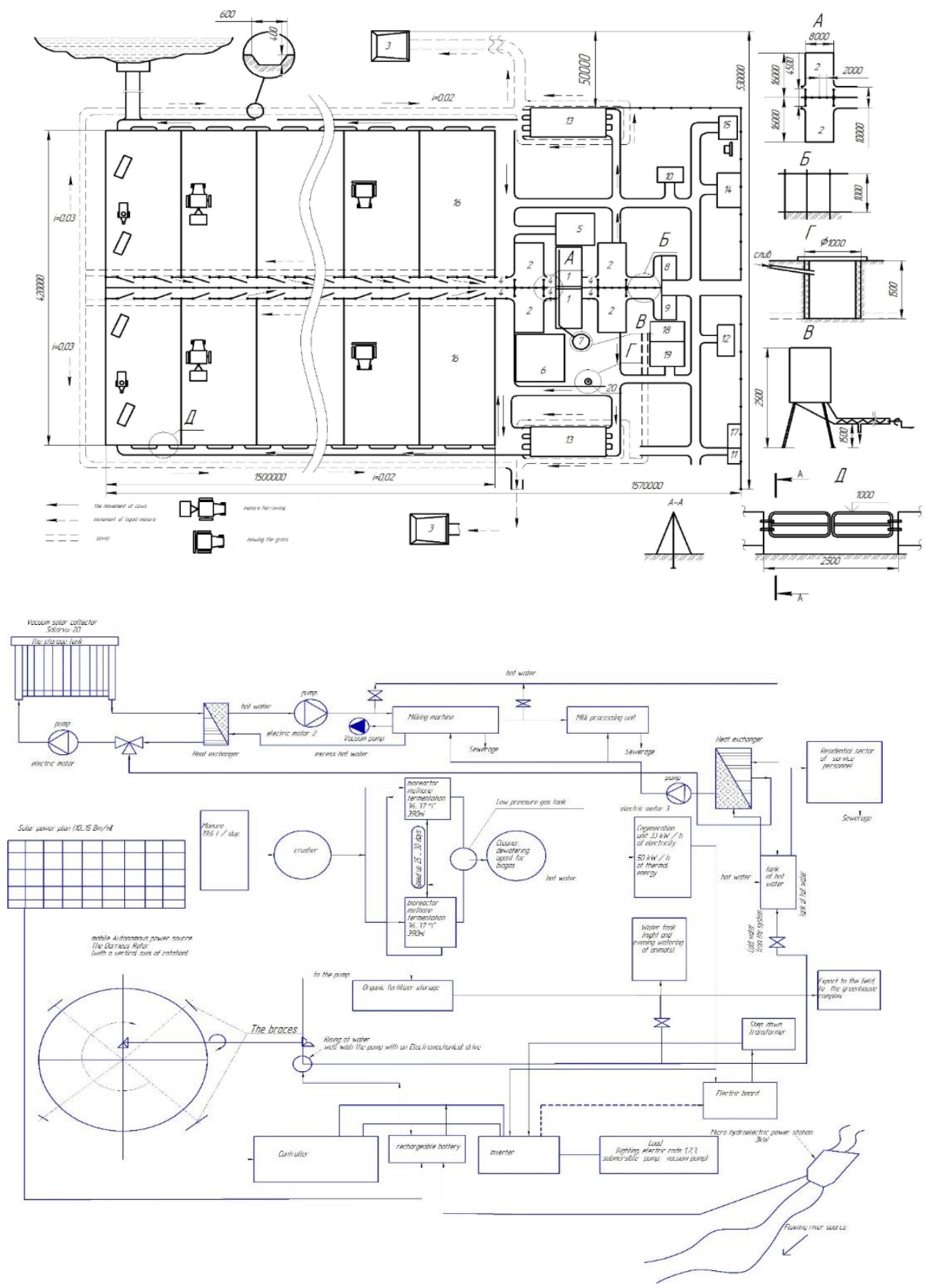

Fig. 4 The communication system of the nonconventional and renewable sources serving pasturable complex 


\section{Conclusion}

1. Increase in intensity of production of milk during the summer period on $10 \ldots 19 \%$ is reached by use of the pasturable milking centers (PMC), due to the technology adapted to terms of use. On the basis of the analysis of references and results of scientific research the most effective remedies of mechanization of production of high-quality milk when providing are revealed $25 \ldots$ the 30 percent level of energy saving.

2. The production technology of milk on pastures (patent No. 2614813) which provides performance of complex of technological processes is developed: upclassing of shelters, feedings and poyeniye of animals, milking and preprocessing of milk, removal of manure and drains. For each its site new technical means are created:

milkings of cows - mode and the device for voltage measurement of initial shift in the pipe duct of small diameter (the patent of the Russian Federation No. 2549537), control system of the water ring vacuum pump (patent No. 2624309);

preprocessing of milk - the reservoir for milk termization in the conditions of pastures (the patent of the Russian Federation No. 2536968), installation for use of natural cold (patents of the Russian Federation No. 2446679, No. 2486749), the device for filtration of milk with cleaning of bacterial impurity (the patent of the Russian Federation No. 153451), the mobile device for transportation of milk (the patent of the Russian Federation No. 95974). 3 . Results of production check of probes show that on the basis of criteria of environmental safety drops of specific energy consumption on production of organic high-quality milk to $5.08 \mathrm{MDzh} / \mathrm{kg}$ allow to reach introduction of the farms of the production technology of milk adapted to conditions on pastures. Introduction of complex of cars in JSC Krasnoye znamya has allowed to get the additional profit of 1.138 million rubles, in LLC APO Collective Farm Mayevsky of Novosokolnichesky district - 920 thousand rub.

\section{References}

1. I.I. Tyukhov, Educational and methodical ensuring teaching course, Nonconventional and Renewables, MESH, 2 (2006)

2. Yu.D. Sibikin, Technology of energy saving: studies (M.: FORUM, 2010)

3. R.A. Amerkhanov, Optimization of agricultural power stations with use of renewable types of energy (Colossus, 2003)

4. V.V.Shevelkov, Analysis of climatic conditions of the Pskov region for the possibility of using the NVE (Pskov publishing house PPI, 14.3, 2011)

5. I.Yu. Dolgov, The power and exegectical analysis of systems of power supply of the agricultural enterprises of livestock production with cogeneration thermal power plants. MESH, 5 (2012)

6. K. Kryukov, Increase in efficiency of collaboration of a solar power plant with industrial network of alternating current, 88(7) (2017)

7. V.V. Nik, About determination of optimum structure of wind-diesel power complexes taking into account local conditions (1976)

8. I.A. White, I.A. Belykh, M.A. Grigoriev, E.V. Belousov, Management system the electric drive for a refrigerating mill, 88(4) (2015)

9. O.A. Gerasimova, Resource-saving technologies of pasturable keeping of cows (Velikiye Luki: RIO VGSH, 2014) 